\title{
Three travellers or how to "translate" Holland to Polish readers: An approach to the image of the Netherlands in Polish travel books
}

\begin{abstract}
Ryszard Kapuściński believed that a journalist was a translator from one culture to another. Therefore, the idea of the paper is to analyse the way contemporary Polish travellers write about the Netherlands. The analysis will focus on the stances adopted by them in relation to the country and the way they determine their perspectives. The authors of the analysed books use keywords as metaphors that permit them to translate complex characteristics of the Dutch. The paper concentrates mainly on three aspects: titles, landscape and mentality.
\end{abstract}

Keywords: the Other, translation, the Netherlands, Holland, tulip, water, gezellig.

\section{Perception of the otherness}

There are different types of otherness. Ryszard Kapuściński (2007) and Marcin Florian Gawrycki (2011) relate it to non-Europeans. They both highlight that we usually tend to use this Eurocentric perspective when we try to define other cultures that have different cultural roots. This kind of thinking determines the way we describe and, in general, understand the Other, because in most of the cases such a postcolonial thinking causes that we treat the Other as worse, weaker, less intelligent. If we use Arjuna Appadurai's (1999) theory regarding creating an image of the others based on essentialization, exoticization and totalization, we can observe that this theory could be applied not only, as he suggested, to the so-called primitive cultures, but while talking about societies that are simply different and not well known either. Although Dutchmen are Europeans, we, Poles, perceive them as strangers from our ethnocentric point of view. The Netherlands 
have always been perceived as different (the other) from the rest of Europe. Yet Charles Baudelaire in Paris Spleen (1896) called it l'Orient de l'Occident, la Chine de l'Europe. Many authors and travellers have tried to understand the mystery of this exceptional land. There are more than 100 handbooks for foreigners who want to visit Holland in which we can find a lot of explanations about the uniqueness of the Dutch, as for instance: The Xenophobe's Guide to the Dutch by Rodney Bolt, Why the Dutch are Different: A Journey into the Hidden Heart of the Netherlands: A Journey into the Heart of Hidden Holland by Ben Coates, The Low Sky in Pictures. Understanding the Dutch. The Book that Makes the Netherlands Familiar by Han van der Horst; Netherlands CultureShock!: a survival guide to customs and etiquette by Hunt Janin and Ria van Eil, The UnDutchables. An Observation of the Netherlands, its Culture and its Inhabitants by Colin White and Laurie Boucke; How to be Dutch by Greg Shapiro; How to Survive in Holland. Dealing with the Dutch Before They Deal with You Martijn de Rooi, etc.

\section{The aims of the analysis}

The idea of this paper is to analyse the process of domesticating the Dutch society in Polish travel books. Among various books ${ }^{1}$ that refer to Holland, ${ }^{2}$ there

1 Among these books there are mainly guides, most of them are translations from other languages (editions of Pascal and National Geographic, for instance) and some of them contain general information about the Netherlands. Before the 20th century we can distinguish a travel book named Holandyja by Stanisław Bełza from 1890. In 1907 Faustyna Morzycka published Holandja. In 1975, Maria Czekańska wrote a book on Holland, named Holandia. It contains a lot of historical and geographical data, but there are no personal observations. This is more like a small guide book about the country. By the end of the seventies, Lech Niekrasz published a small book titled Holland. Maty przewodnik turystyczny (1977) in which he presented some practical information about the Netherlands. Already in the first sentence he highlights the uniqueness of the country determined by water and religion. Three years later Kazimierz Koźniewski wrote Dostałem Niderlandy (1980), an interesting book in which he confronts his impressions from the first journey from 1937 with the journey in 1977. The forty-year gap is the source of reflections, observations of the Netherlands that had changed a lot due to historical, political and social circumstances. Lech Niekrasz published one more book in 1986 Kraj na przekór naturze, which also contains a lot of information about the geography and history of the Netherlands, although there are not many personal reflections. As for the reportage we should mention as well Kamil Bałuk's Wszystkie dzieci Luisa (https://www.kamilbaluk.pl/english.html), which refers to Holland, but the aim of the book is a journalistic investigation, not the description of the country. Another book that focuses on one aspect is Ryszard Żelichowski's Baarle Nassau-Hertog (2015), which is dedicated to the historical particularities of this zone. It is worth mentioning that some of the books concentrate on one part of Holland as for example In Amsterdam published by Gazeta Wyborcza.

2 The authors of the analysed books prefer to use the term "Holland" referring to the whole country in general, but it should be explained that the appropriate word is the Netherlands. Holland refers especially to two provinces: Noord- and Zuid-Holland, all 12 provinces are the Netherlands. In this paper the terms are used interchangeably in reference to the whole country. 
are three that distinguish by the form and structure, because they are based on journalistic genres (literary journalism, essay, mini-essay and feuilleton) and are not conceived as typical guides: Mirosław Popczyk Na saksy! Raport z Holandii (1994), Marek Orzechowski Holandia. Presja depresji (2014, 2019), Piotr Oczko Holandia. Książka do pisania (2019). ${ }^{3}$

I would like to focus on Popczyk (a journalist, foreign correspondent), Orzechowski (a journalist, foreign correspondent) and Oczko (a professor, works at the university). These three authors are not simple voyagers, but very conscious and curious travellers who tend to learn as much as possible and they feel somehow responsible for transferring their knowledge. What is interesting is the fact that they adopt different attitudes towards the country, the society and the relationship between Poland and the Netherlands.

\section{The methodology of the research}

The methodology of the research is based on determining the three dominant stances and their influence on the perception of the Dutchmen, their culture, habits, history, positive and negative features in relation to keywords excerpted. Each of the selected authors shows a close connection with Holland and has visited the Netherlands many times, the books are not based on a singular visit, but they are the result of years of experiences, hence a strong feeling of admiration, the need to show and explain things. Furthermore, these three books are interesting to analyse also because there is a gap of almost forty years between them. Popczyk visited Holland at the beginning of the nineties, as a foreign correspondent, which coincided with Polish transition. It was the moment when the Iron Curtain was abolished and many people from Poland travelled to earn money for a better life. It is relevant to show what changes occurred in the meantime and how they influenced the perception of the Netherlands. While Popczyk and Orzechowski are journalists and Oczko is not, for the purpose of the article I will use the term 'traveller' to refer to them.

Ryszard Kapuściński (2008) used to say that a journalist is a translator who translates from one culture to another. He, as a traveller and a reporter, created his own, particular, style based on what I called translation method (Kolankowska 2021). The journalistic piece/ reportage is thus an example of the intra- and intercultural translation in which phenomena, habits, etc. are explained by details, symbols, namely signs that are clearer and more understandable for the receivers.

3 Piotr Oczko published essays on Holland in a monthly Znak between 2018-2020. In autumn 2021 "Wydawnictwo Znak" is going to publish his essays in a book named Pocztówka z Mokum. 21 opowieści z Holandii and they will certainly shed a light on many issues tackled in the analysed books. Unfortunately the book is unavailable before the submission of this article. 
According to the scheme created by Franciszek Grucza and developed by Barbara Kielar (7), we can affirm that in the scheme presented below, a journalist is an Intermediate Receiver and Intermediate Sender, yet he receives/reads the signs and transfers them to the Final Receiver:

Initial Sender $\rightarrow$ Text $\mathrm{A} \rightarrow$ Intermediate Receiver $\rightarrow$ Intermediate Sender [TRANSLATION] $\rightarrow$ Text B $\rightarrow$ Final Receiver

The process of translation in this context is based on journalistic experience, knowledge, studies, books, etc. and text B is what we receive as a reportage, column, chronicle, or a book. In my opinion, the three travellers use the same method, although not everyone is aware of it. They even use the same terms to 'translate' determined aspects of habits or behaviours intrinsic to Dutchmen.

The attitudes adopted by the three travellers allow us to treat them as Intermediate Receivers/Senders, although the way they translate differs because of the stances. In the selected examples, we can observe the admiration connected with three predominant stances: shame (Popczyk), astonishment (Orzechowski) and longing (Oczko). Each of them is determined by personal experiences, each of the stances influences both the form and the structure of the book. One can say this is a simplified and maybe insufficient, or even belittling perspective, but I will try to show, how strong the conviction and its influence on the narrative is. The analysis will be focused on three main aspects that seem to determine the image of the country in the three books: titles, landscape and mentality.

\section{The analysis of the titles}

Let us analyse the titles first. Popczyk's book is titled Na saksy! Raport z Holandii, which can be translated as Let's earn money! A Report from Holland. This first expression was the most often used during the Polish transformation, when many people travelled to German Saxony to earn money, later it has been used for every type of a trip made in order to earn money, particularly, referring to work off the books. This is the usage Popczyk refers to in his book. He is a sport journalist and he has travelled a lot to Holland. In a short biography, the author explains that he is especially interested in the life of Poles working off the books. Some of the reportages included in the volume had been published in newspapers such as Dziennik Pojezierza, Gazeta Wspótczesna from Białystok, Dziennik Częstochowski and in a monthly Sukces. There is no clear, chronological order in the book, that is why one can have an impression of reading a set of pictures from various places. They are like puzzles forming the picture of Holland in the early nineties. In the introduction, Popczyk mentions a booklet that was supposed to be a guide on how to find work in Western Europe: "Browsing the pages, I realized that I have a kind of a label of Polish changes, changes that, unfortunately, lack 
of ethics, dominated by the slogan: "no holds are barred"' (3). He highlights that there are different motivations of leaving the country, either desperation, the lack of prospects or sense of adventure. Many of migrants go to Holland with the hope for a better future, he calls them using a German word gastarbeiter (referring to a German guest worker program Gastarbeiterprogramm). Popczyk states that there is still a lot of kindness, but it is decreasing because of a "new, unpleasant image of a Pole" (5). This is actually the reason for shame that accompanies the reporter during his journey. In his narration, we can observe both either the inferiority complex or being ashamed of countrymen. He does understand their need to find a job, to work, even off the books, but he cannot understand breaking the rules (thefts, fraud, drunkenness, partying, etc.).

According to numbers quoted by Popczyk, in 1989 there were 30,000 Poles in Holland and in 1990 the number increased to 60,000. Popczyk explains that Polish citizens set off to Western Europe "as conquerors to the promised land" (16). The journalist travels with them, talks with them, sometimes even has to escape from the police with them. During his journey he is continuously observing the country and he is trying to find the key elements of the Dutch mentality. In the narrative, we can distinguish some clue categories: landscape, history, habits, food, features, Poles vs. Dutchmen.

Popczyk emphasizes that this is a "low country" (neder-land), but does not concentrate much on this aspect, whereas this is a key element for Orzechowski, which he underlines in the main title Holland. The Pressure of Depression. The author alludes both to depression as a geographical term and to a state of mind. Orzechowski is a writer, journalist, essayist, who used to work as a correspondent for the 'Voice of America' in Bonn and for the 'TVP' and 'Polsat' television. He, as Günter Verheughen says in a blurb, "does not dissemble that he loves Holland" and this is why he tells the truth, undercovers what lies under the first, somehow misleading, layer. While reading the book, which is a mixture of reportages and essays, the reader realizes that the author is not a newcomer, but an experienced and conscious traveller who knows a lot and tries to describe and explain all that he discovered about the Netherlands and its particularities. The feeling that accompanies him can be referred to as astonishment, either positive or negative, but the one that provokes him to study and learn more about the culture he admires so much. The narrator is aware of the unpredictability of the country, well-known, but fascinating as we read in this paragraph:

However, it is not important whether we devote many days and many hours to the Netherlands, whether we are not idle while exploring it, whether we spend holidays there and visit our friends - the Netherlands will always surprise us and it will always be a country to be discovered. This can be a fishing village that we have passed by many times from the distance, which we have never visited. Or a fragment of coastal shafts with dunes in the autumn suddenly revealing their so unnatural beauty that one would like to lie on them, fall asleep, find solace among the endless symphony of strong wind (Orzechowski 130). 
Oczko's (2019) book is different than the previous ones. Its name is $\mathrm{Hol}$ land. A book for Writing. This is a set of photos accompanied by texts that can be compared to postcards and... blank, numbered, sheets. The idea of the editor of the series, "Wydawnictwo Austeria", is to encourage a reader to make notes in the book, thus the author, the traveller, invites a reader to accompany him in the trip, to be an active, not passive, receiver; he asks for a reaction, as if he invited the reader's interpretation, reflection, completion of what has been said. Oczko's texts have a structure of mini-essays that resemble feuilletons. $\mathrm{He}$ usually commences writing with a personal anecdote related to Holland and then develops the story and leads it to a strong, clear conclusion. The black and white photos express melancholy and longing to visit the places once again. He says: "I will take you to some places. This is not going to be a guidebook in which you will find tourist attractions, but a story about longing" (Oczko 6).

\section{Elements of landscape as keywords}

All three travellers have no doubts that this is an exceptional place, especially when we think about its location and landscape.

The depression is a keyword, strongly related to water. Both depression and water are signs/texts B that are used by Orzechowski to explain, or translate, one culture to another:

And this is how it is. Water decides about everything - about the look of cities and settlements, about production, economy, agriculture and the characters of people. Water is a friend and an enemy too. One third of the country lives under the sea level, one third is elevated one metre above the sea level. No other country is so much exposed to floods and so much threatened by them (Orzechowski 52).

Fighting with water for ages, as Orzechowski proves, has determined the strong characters of the Dutch. He compares this challenge, related especially to Zuiderzee, to Ikar's challenge that seems to be impossible, but the Netherlands has harnessed water by building channels, dams, polders. Water creates the landscape and influences the structure of cities and the countryside. Water influences the internal division of the country, contributing to even more differences. Water influences the way of people's lives, their food and needs. Orzechowski shows that living in the permanent contact with the unpredictable force can be either the source of strength or weakness.

Foreignness, as many anthropologists, for example Mieczysław Dąbrowski (2009), emphasize, is the feeling that helps us to see and understand more of the reality that is experienced as different: "strangeness is a need in the cognitive process, especially in the process of self-awareness. It is a stimulating and catalysing factor, without a stranger there would not be a familiar, without strangeness 
we would not understand what familiarity means" (Dąbrowski 167). In this case, Orzechowski looks through the eyes of an astonished foreigner, especially when he is standing on a dam:

\begin{abstract}
It is worth stopping on it, leaving a car on a small car park and going outside. It is worth, in a sense of safety and the advantage over the element, looking the sea straight in the eye, it is worth feeling the strong wind on your face. It is here that a man breathes with a conviction that he reigns over the world. It is here that a man does not have to be ashamed of his own conceit, because if he had been able to create such a large dam in the middle of the stormy sea, he is able to do everything. Distant polders, where normal life is flourishing, is not visible from here, but it is enough to look into the depths of waves hitting the dam to understand that the nation which like no other could confront with the sea and was able to stand on its bottom with a dry foot, deserves great respect (Orzechowski 54-55).
\end{abstract}

This excerpt shows the admiration and respect, Orzechowski admits that in such circumstances he is able to forgive the parsimony and small mindedness of the Dutch: "It is me, surrounded by the stormy wind, who in my own eyes became petty and unforgiving, I was ashamed of my views taken from warm rooms and a dry land, not comparable to their - soaked and with water in their wellingtons" (55).

Both Oczko and Orzechowski show that water has been harnessed by Dutchmen. Water is "capricious" and "erratic" (Oczko 14), but the inhabitants of this land are stronger and they know very well how to deal with water. The most surprising is the subjugating of the Zuiderzee. It appears in both books: a man is taking the land away from water. Additionally, Oczko observes that water determines the way of living, he pays attention to houses on dams. He affirms they might have been built by dwarfs - this kind of narration transforms the Netherlands into the magic land where people live in small houses (small, because of the milieu): "They have fancy, covered with creepers, colourful facades, funnyshaped windows and doors with a knocker" (Oczko 14). This idyllic image is completed by a description of their life: "The inhabitants put the tables on the street, eat supper and talk to neighbors" (Oczko 14). Once water is calm, the life is slow and people feel safe and comfortable. The traveller is an observer, but he is also a little bit jealous, he rides a bike, watches, observes and wants to be a part of that reality, he wants to domesticate the strangeness that he recognizes as admirable, although he is aware of being a stranger as well.

Orzechowski sees even more in the landscape. When he looks at the map of the Netherlands, he discerns dividing lines of different types. Especially on the East-West and the North-South line. First of all, he emphasizes that the Netherlands is not only Holland, the differences are of many kinds, based on landscapes, temperament, mentality, religion, power, even language as in the case of plattdeustch, based on cultural and historical background. The journalist is aware that most people base their image of the Netherlands on stereotypes, because the visitors see only the external layer: 
The differences are not so visible for the newcomers, they see everywhere clean and neat homesteads, big windows, laces on the windowsill, blue and dark-green doorframes, calm channels, levees and windmills, patient cows and old bicycles, naked legs of Dutch women even when it is cold. You need some time and hiking on distant paths to understand that not everything is as simple as a pasture and as colourful as the endless rows of colourful tulips (Orzechowski 31).

This statement shows the urge to explain what was somehow established by journalists like Popczyk, trying to show that flower is a keyword for understanding the Netherlands:

Flowers, flowers, flowers everywhere. In the windows of houses, in gardens, shop's exhibitions, in buses, in flowerpots of concrete, and, first of all, in the fields. In the countryside, as far as the eye can see, the never-ending acres of tulips, daffodils, crocuses, narcissuses, hyacinths. From Lisse to Rijsburg, from Nordwijk to Hillegom, from Harlem and Amsterdam to Den Helder. This is as if someone put colourful blankets. Here a red thread, there a yellow one, over there violet, and there white, and over there pink (Popczyk 21).

Popczyk pays attention to the fact that flowers are related to hard work and the competition between planters. Flowers are related to gastarbeiters, however it will be discussed below. Orzechowski proves that these fields blanketed with flowers are misleading: yes they are a part of the landscape, but they do not mean that Dutch have a romantic nature, on the contrary, they are perfect at hiding the truth about their dark side.

To conclude this part dedicated to landscape, we can indicate the fundamental keywords that are used as tools for translation. These are: depression, water, dam, window, small houses, flowers (tulips). The travellers use them to show the dissonance between the image (stereotipized) and the truth. Particularly Orzechowski shows that the process of essentialization and exoticization, in this particular case based on fascination and admiration of the landscape and order, leads to totalization, simplification and idealization of the country. The Other that they meet in the Netherlands is observed from the ethnocentric perspective and is being familiarized step by step. He is not a stranger anymore, he is different, the Other, but familiarized, domesticated, therefore the traveller can perceive more and more and share it with the readers, translate. As Dąbrowski (2009) claims: "The familiar/strange opposition in the background suggests the existence of the limit, some kind of passage between the first and the second field; of a line, a word, a habit that either bind or separate".

\section{Dutch mentality vs. Polish mentality}

Tulip, being an element of the landscape, is the keyword for another category which, paradoxically, is the Dutch mentality. Orzechowski uses this flower to talk (translate) about the nature of inhabitants of the Netherlands: "A tulip is 
beautiful till it stands proudly in the pot and extremely hideous when it withers. It is probable that this is the price it pays for its fleeting beauty. And it is probable that, like no other flower, it pictures the character of the moral ambiguity of Dutch, who as no one else knows how to cultivate tulips" (320). At this point the author refers also to Jacek Cygan's song about tulips. The use of the song to reinforce the metaphor is a perfect example of intersemiotic translation by the use of signs. Orzechowski tries to show something that is invisible, a feature that he has observed and filtered through his personal experience.

Orzechowski is very critical about Dutchmen. A great part of the book is dedicated to the historical background. The traveller feels obliged to refer to the whole history of the Netherlands, because it reveals the dark side of the nation. In the past, he finds another keyword which is the Flying Dutchman, a mythical Dutch-flagged clipper. The chapter about this figure is written as a magical realism novel. The reader has an impression as if the Flying Dutchman still existed. What the writer tends to prove is that this mythical idea is still somehow present in the mentality, because the legend embodies the eagerness to be on the sea and to look for the unknown lands. This need was an answer to the boring reality and stagnation of the then Dutchmen. This keyword is particularly interesting, because Orzechowski compares the situation of the then Netherlands and Poland: "The Wild Fields were our ocean" (89), he affirms, showing the difference between the needs of both nations. He is continuously showing that these two nations have developed in a different way, because of the situation, the circumstances. The Dutchmen knew how to invest money, speculate on the stock market and buy Manhattan for a very good price and invent "the trade with air" (he alludes to the sophisticated tax system).

This historical part of Orzechowski's book shows the ambiguous attitude of Dutchmen towards Jews in various moments in the past, especially during the World War II. He accuses them of collaboration with Nazis, growing rich on deportees' properties and especially of supporting the Nazis in their racist policy, hate and helping to catch Jews during the World War II. He Orzechowski accuses them of indifference toward the persecuted, collaboration with Nazis, growing rich on deportees' properties and especially of supporting the Nazis in their racist policy (instead of supporting the persecuted people), hatred and helping to catch Jews during the World War II. This issue is, in Orzechowski's opinion, one of the main unsolved problems of Dutch collective memory. There is still a need of reckoning the past, as he affirms (Orzechowski 297-323). In order to explain this attitude the traveller (Orzechowski 321-322) uses a metaphor:

In 2012, during an auction an anonymous collector paid 120 million dollars for a painting by a Norwegian expressionist, Edvard Munch, called The Scream. In the painting we can see a figure of a man standing on a bridge. He is not alone there, but still he is lonely. A scream is coming from his open mouth, so sharp that it pierces right through and forces one to plug 
ones ears. The scream is terribly silent and terribly audible. When I look at this painting, I can see the attitude of the Dutch during the Nazi occupation. I can see the resistance of the Dutch, their fight with the occupant, I can see their objection, their scream, which on the contrary to Munch's Scream is absolutely silent, deprived of sense - and like their resistance towards the Nazis, it is the scream of silence.

Human trafficking and slavery is another delicate issue. Talking about it, Orzechowski demonstrates that it has cost them a lot to admit the inconvenient truth. He alludes here to year 2002, when the queen Beatrix unveiled the monument for the victims of human trafficking. Orzechowski observes that only 5 percent of ten millions of slaves were slaves brought from Africa by the Dutchmen, but at the same time he openly asks: "But do these five percent correspond to five percent of guilt, five percent of penance? Does this colonial vest have only one dirty stain and because of this it is clearer than the other ones?" (Orzechowski 116). These comments related to the dark side of Dutchmen are the expression of the astonishment. Each step, each revelation shows him the ambiguity of this society. Getting familiar with the history, he discovers the otherness between the two nations and understands (and explains it to the receiver) that the geographical and historical backgrounds determine the perspective. He emphasizes that what is external is related to the internal features, mentality, hence the difficulty in understanding or misunderstanding. These reflections lead him to an explanation of the stereotypes that nowadays make us treat the Netherlands as the country of free love, drugs, flowers, tolerance, windmills and cows. The reportages and essays show that this is a very superficial image of the Netherlands. The only way to see the truth is to know the past and discover what the Dutch usually hide inside. And he knows they hide a lot in relation to Poles. Orzechowski dedicates a lot of space to comments concerning Polish veterans who had to wait many years to be respected and recognized as heroes. This is not the only accusation against Dutchmen. The journalist reports the debate in the Dutch parliament in 2004, just before the Polish accession to the European Union. He writes about "national chauvinism", hate against Poland, expressed by those who did not know the country: "We were reduced to whores and, thieves, hooligans, drunkards and slyboots who are on the scrounge. In the press office it was generally gezellig, ${ }^{4}$ but I was sitting like a leper" (Orzechowski 371).

4 Gezellig and gezelligheid are Dutch words that are considered by travelers to be untranslatable as they refer to feelings. It could be compared with the Danish hygge, the German Geselligkeit or the French convivialité, as a feeling of a 'cosy conviviality'. It is often used to describe a social and relaxed situation (see e.g. Colin White and Laurie Boucke, The UnDutchables: an observation of the Netherlands, its culture and its inhabitants $\left(1989^{1}\right)$. On the other hand gezellig is an adjective that can refer to a room, a person, a party, etc. and it means that this is nice, pleasant, cosy, relaxed and friendly atmosphere. As it is hard to find an appropriate translation in Polish, the 'travellers' look for signs/situations/images to express the meaning of these terms. 
Popczyk is not so profound in his reflections about the Dutch. He is ashamed of his compatriots and he sees the order, a well-organized space, and luxurious life. This is what he does not have and one can get an impression of him being jealous. What is the most important is that he observes that the Dutch are friendly and kind to Poles, even the police somehow helps them. He describes a situation in which his compatriots have to escape from their work (off the books) because of the police raid. What he emphasizes is that, to tell the truth, the Dutchmen do not want to fight with Polish immigrants, because they do need them for work.

Both Orzechowski and Oczko agree that gezelligheid is the main keyword to comprehend the mentality of the Dutch. Both explain that you have to experience it to understand what it means. This refers to a state of mind, of feeling well and safe. On the one hand, Orzechowski translates it using the word coziness. This is the way to find solutions even in apparently complicated situations. But, as he explained referring to the parliamentary debate, this is what belongs to the external layer of the Dutchmen: "Gezellig is nice, but superficial, gezellig is likeable, but it defends the access to its soul. Gezellig is to hide the essence" (Orzechowski 365). On the other hand, Oczko affirms this is a "word-institution" (54) and in order to explain it he uses a picture, translates one sign using another one:

In a cosy room a happy family is having coffee and biscuits, there is a fire burning in the chimney or the candles are lighting, there is an undistorted mood of kindness, it is probable that it is raining outside, but everyone all the time repeat zo gezellig (so nice, homely, so good). For me, gezellig is a small village Noord-Sleen in the province of Drenthe. Punctually at ten o'clock Jan withdraws the books, prints and blue plates we have been working on for the whole evening, ceremonially brings a tray with glasses of old Porto, crackers and cheeses from the kitchen. Henny puts aside one of the patchworks, inserts the needle in the velvet pillow, tidies the patches of material and joins the conversation. How many buds of primrose are going to open tomorrow? (Oczko 54)

This poetic picture is an example of intersemiotic translation. A term that is untranslatable is explained in a different way, as filtered by the traveller's experience. He is no more a stranger as he feels the same. He experiences the coziness and closeness; he is not as cynical as Orzechowski. He domesticates the Other and is being domesticated by him as well. He is fascinated by the Dutch culture and wants to feel a part of the society. His longing is expressed in the need of recovering the memories and reviving the moment. The blank sheets invite the reader to describe his own experience. This perspective, based on strong feelings, is more open, but could be interpreted as well as idealization of the Other. Oczko confesses that he has a lot of friends, he mentions especially Gerdien with whom he feels a special bond which is "emotional schizophrenia, characteristic for the people who have split into two countries" (Oczko 198). They both love each other's countries and culture. The book is an expression of eagerness to revive all these good moments, gezellig. This idealized vision contrasts with Orzechowski's 
perspective in which Dutchmen are hospitable, but miserly. What is repeated in all the reports is the capacity of Dutch of having fun with no need to always show a little front, as it is common in Poland.

The relationship between Poles and the Dutch is visible in all three texts, although the descriptions differ from one another. Popczyk is ashamed because of the behaviour of his compatriots, he reports thefts, frauds and other offences. $\mathrm{He}$ feels responsible for showing it in order to prevent people from doing the same. The Dutch he meets are kind and usually open to help Poles, some of them even offer a place to live, invite for a meal, because they feel sorry for the poor immigrants. These poor immigrants, living in precarious conditions, are not so interested in knowing the country, they come to earn money and come back to Poland. Holland from Popczyk's book is a symbol of a luxurious life.

The Dutch from Orzechowski's book are ambiguous. He shows his astonishment, sometimes shock, sometimes even anger, as he discovers the dark side of the Dutch. But he does not condemn the nation. He criticizes them openly, but the reader still has an impression than the admiration and respect are stronger, predominant feelings.

Oczko loves the Netherlands. He is a foreigner, but he has tamed the country and he has been tamed. He has learned a lot and when he rides a bicycle on a dam, he feels as if he were at home.

\section{Conclusions}

These three authors, from different times, with a different background, have portrayed the Netherlands in their books. They tried to express and transfer their feelings and observations. The idea of this paper was to track the keywords, main categories, influenced by the three stances. They all demonstrate that there are some objective elements of the Dutch reality that can be easily detected, as water, dams, channels, fields, but there are also a lot of invisible elements that need time to be discovered. The relations between the two countries have been of many kinds, in the last three decades, determined by looking for an odd job, and looking for freedom and tolerance. These reportages and essays show there is a need for translating one culture to another, to understand it in order to be able to tame the Other. When we domesticate the Other, when we are able to see, listen to and experience things in a similar way, we are gezellig. The travellers quoted here feel responsible for transmitting their knowledge, opening hearts and minds. Piotr Oczko expresses it even in the structure of his book: white, blank sheets invite readers to write and share; this is the way to be closer to the Other. 


\section{Bibliography}

Appadurai, Arjuna. "O właściwe miejsce w hierarchii”. Amerykańska antropologia postmodernistyczna, edited by Michał Buchowski. Instytut Kultury, 1999, pp. 228-244.

Bałuk, Kamil. Wszystkie dzieci Louisa. Dowody na istnienie, 2017.

Baudelaire, Charles. Le Spleen de Paris, Petits Poèmes en Prose, "L'invitation au voyage", Classiques Larousse, XVIII, p. 34, Editions de La Pléiade, XVIII, p. 301.

Bełza, Stanisław. Holandyja. G. Gebethner, 1890.

Bolt, Rodney. The Xenophobe's Guide to the Dutch. Oval, 2008.

Coates, Ben. Why the Dutch are Different: A Journey into the Hidden Heart of the Netherlands: A Journey into the Heart of Hidden Holland. Nicholas Brealey Publishing, 2015.

Czekańska, Maria (Composition and structure Jan Hattowski). Holandia. Wiedza Powszechna, 1975.

Dąbrowski, Mieczysław. "Swój/ obcy/inny. Kontynuacja”. Anthropos? (Anthropos?), issue 12-13, 2009, pp. 164-176, www.ceeol.com. Last consulted on 15th of August, 2021.

De Rooi, Martijn. How to Survive in Holland: dealing with the Dutch Before They Deal with You. Dutch Publishers, 2007.

Między nami Cafẻ. IN Amsterdam. Agora S.A. Wydawnictwo Promocyjne Między Nami, 2011.

Gawrycki, Marcin Florian. Podgladając Innego. Polscy trawelebryci w Ameryce Eacińskiej. Wydawnictwa Uniwersytetu Warszawskiego, 2011.

Hunt, Janin, and Ria van Eil. Netherlands Culture Shock!: a survival guide to customs and etiquette. Marshall Cavendish, 2005.

Kapuściński, Ryszard. Autoportret reportera. Biblioteka Gazety Wyborczej, 2008.

Kapuściński, Ryszard. Ten Inny. Znak, 2007.

Kielar, Barbara.Zarys translatoryki. IKL@Wydawnictwo Naukowe Instytutu Kulturologii i Lingwistyki Antropocentrycznej, Uniwersytet Warszawski, 2013.

Kobus, Anna, and Krzysztof Kobus. Holandia. National Geographic, 2012.

Kolankowska, Małgorzata. "Klucze do zrozumienia Latynoameryki w reportażach Ryszarda Kapuścińskiego". Literatura latynoamerykańska na warsztacie współczesnych badaczy w Polsce $i$ w Czechach, edited by Danuta Mucha. Wydawnictwo Uniwersytetu Jana Kochanowskiego w Kielcach, 2021.

Koźniewski, Kazimierz. Dostałem Niderlandy. Iskry, 1980.

Morzycka, Faustyna. Holandja. Księgarnia Polska, 1907.

Niekrasz, Lech. Holandia. Mały przewodnik turystyczny. Krajowa Agencja Wydawnicza RSW "PrasaKsiążka-Ruch”, 1977.

Niekrasz, Lech. Kraj na przekór naturze. Nasza Księgarnia, 1986.

Orzechowski, Marek. Holandia. Presja depresji. Muza, 2014 (2019).

Oczko, Piotr. Holandia. Książa do pisania. Wydawnictwo Austeria, 2019.

Popczyk, Mirosław. Na saksy! Raport z Holandii. Wydawnictwo Ethos, 1994.

Shapiro, Greg. How to be Dutch. Scriptum Publishers, 2017.

Van der Horst, Han. The Low Sky in Pictures. Understanding the Dutch. The Book that Makes the Netherlands Familiar. Scriptum, 2006.

White, Colin, and Laurie Boucke. The UnDutchables: an observation of the Netherlands, its culture and its inhabitants (first published in 1989).

Żelichowski, Ryszard. Baarle. Nassau-Hertog. Instytut Studiów Politycznych PAN, 2015. 